University of Nebraska - Lincoln

DigitalCommons@University of Nebraska - Lincoln

Agronomy \& Horticulture -- Faculty Publications

Agronomy and Horticulture Department

$11-1958$

\title{
Influence of Seed Irradiation with X-Rays and Thermal Neutrons upon Cell Size and Mitotic Activity in Root Tips of Maize
}

\author{
Francis A. Haskins \\ University of Nebraska-Lincoln, fhaskins@neb.rr.com \\ Merwyn Davidson \\ Evangelical Theological Seminary, Naperville, Illinois \\ Russell Beers \\ Department of Bacteriology, lowa State College, Ames, lowa
}

Follow this and additional works at: https://digitalcommons.unl.edu/agronomyfacpub

Part of the Plant Sciences Commons

\footnotetext{
Haskins, Francis A.; Davidson, Merwyn; and Beers, Russell, "Influence of Seed Irradiation with X-Rays and Thermal Neutrons upon Cell Size and Mitotic Activity in Root Tips of Maize" (1958). Agronomy \& Horticulture -- Faculty Publications. 167.

https://digitalcommons.unl.edu/agronomyfacpub/167
}

This Article is brought to you for free and open access by the Agronomy and Horticulture Department at DigitalCommons@University of Nebraska - Lincoln. It has been accepted for inclusion in Agronomy \& Horticulture -Faculty Publications by an authorized administrator of DigitalCommons@University of Nebraska - Lincoln. 


\title{
INFLUENCE OF SEED IRRADIATION WITH X-RAYS AND THERMAL NEUTRONS UPON CELL SIZE AND MITOTIC ACTIVITY IN ROOT TIPS OF MAIZE*
}

\author{
F. A. HASKINS, MERWYN F. DAVIDSON, $\dagger$ AND RUSSELL J. BEERS $\ddagger$ \\ Department of Agronomy, University of Nebraska, Lincoln, Nebraska
}

In recent years a number of reports (for example, Caldecott et al., 1952, 1954, 1955; Schmidt and Frolik, 1951; Schwartz, 1954; Schwartz and Bay, 1956; Spencer and Cabanillas, 1956; Yagyu and Morris, 1957) have appeared which deal with the effects of treating seeds with various high energy radiations. In all cases it is reported that seedlings grown from appropriatelyirradiated seeds are reduced in stature. This reduction in stature must necessarily result from irradiation-induced decreases in number and/or size of the cells comprising the seedlings. Although some quantitative data relating to irradiation-induced changes in cell size and mitotic activity are available in the literature (Lea, 1955), there is a paucity of this type of information dealing with the seedlings grown from irradiated seeds. This report deals with a study in which cell size and mitotic activity have been measured in tips of roots grown from control and irradiated maize seeds.

\section{MATERIALS AND METHODS}

Seeds of the single-cross maize hybrid, L289 $\times$ I205, were used in these studies. X-ray and thermal neutron treatments were administered at the Brookhaven National Laboratory, under the supervision of Dr. Seymour Shapiro. The irradiation procedures were similar to those which have been described elsewhere (Haskins and Chapman, 1956).

Thirty-five seeds from each treated lot and from a control lot were immersed for five minutes in a 1 per cent sodium hypochlorite solution, rinsed several times in distilled water, and allowed to germinate at $24^{\circ} \mathrm{C}$. in moist vermiculite in the dark for a period of about 65 hours. After this germination period, seedlings were washed free of vermiculite and were sorted according to length of primary root into four groups of seven or eight seedlings for each of the treatments. Following measurements of root length, the terminal 3-mm. portion of each primary root was removed and placed in a fixative solution prepared according to the directions of Randolph (1935). The fixed root tips were dehydrated and mounted in paraffin by standard cytological procedures. A rotary microtome, set for a thickness of $11 \mathrm{mi}$ -

*Research was conducted under Contract No. AT (11-1)-393, United States Atomic Energy Commission. Published with the approval of the Director as paper No. 896, Journal Series, Nebraska Agricultural Experiment Station.

†Present address: Evangelical Theological Seminary, Naperville, Illinois.

$\ddagger$ Present address: Department of Bacteriology, Iowa State College, Ames, Iowa. 
crons, was used for longitudinal sectioning of the root tips, and the resulting serial sections were stained with crystal violet-iodine stain and mounted on microscope slides. These slides were stored until measurements and counts could be made. The four groups of tips from each treatment were kept separate from each other throughout the procedure.

Measurements of cell size were made with the aid of an ocular micrometer mounted in a microscope. Magnifications of ocular and objective lenses were $10 \times$ and $43 \times$, respectively. Under these conditions, one micrometer scale division was equivalent to 3.3 microns. Measurements were recorded to the nearest 0.1 scale division. Cells were measured in two regions of the root tip. For region I, measurements were confined to an area approximately 100 microns from the rather definite line separating the root cap from the remainder of the tip. Laterally, region I measurements were confined to the center portion of the section. There was little, if any, evidence of differentiation in this portion of the root tip. Lengths and widths (that is, the dimensions roughly parallel to the long axis of the root and at right angles to this axis, respectively) of five randomly-selected cells in one section from each tip were determined. Where possible, measurements were made on six tips from each of the four groups within each treatment. Thus, except in those instances where some tips were lost during the dehydrating, sectioning, mounting, and staining procedures, 30 cells per group, or 120 cells per treatment, were measured.

For region II, measurements of length and width were taken on cells lying approximately 650 to 850 microns from the line separating the root cap from the remainder of the tip. In this zone, considerable differentiation had occurred. Measurements were confined to the outer few layers of cells, where five randomly-selected pairs of cells were measured on a single section from each tip. Pairs of cells were used because, in this region, orientation of the cells made this procedure somewhat more convenient than measuring single cells. Each pair consisted of two cells adjacent to each other in the direction of the long axis of the root. Region II measurements were made on the same sections which were used for region I measurements.

An indication of the influence of the treatments upon mitotic activity was obtained by making counts of dividing cells in the root tip sections. As in the measurements of cell size, six tips per group (24 tips per treatment) were observed where possible. For each tip observed, counts were made on the terminal 330-micron portion of 10 individual sections. Thus, 240 sections per treatment were counted where possible. Cells which appeared to be undergoing any stage of mitosis were counted as dividing cells.

\section{RESULTS AND DISCUSSION}

Mean lengths of the primary roots from each treatment, and of the roots comprising the four groups within each treatment, are shown in table 1. At the particular seedling age which was used, distinct reduction of root length was observed only at the highest levels of X-rays or thermal neutrons. Ef- 
TABLE 1

LENGTHS OF PRIMARY ROOTS USED IN STUDIES OF CELL SIZE AND MITOTIC ACTIVITY

\begin{tabular}{|c|c|c|c|c|c|c|}
\hline \multirow{3}{*}{ Treatment } & \multirow{3}{*}{$\begin{array}{l}\text { Number of } \\
\text { useable } \\
\text { seedlings }\end{array}$} & \multicolumn{5}{|c|}{ Length of primary root (mm.) } \\
\hline & & \multicolumn{4}{|c|}{ Group means } & \multirow{2}{*}{$\begin{array}{c}\text { Treatment means } \\
\text { and } \\
\text { standard errors }\end{array}$} \\
\hline & & 1 & 2 & 3 & 4 & \\
\hline Control & 29 & 47.4 & 44.1 & 40.3 & 26.9 & $39.9 \pm 1.72$ \\
\hline $\begin{array}{l}10,000 \text { r X-ray } \\
20,000 \mathrm{r} " \Rightarrow \\
40,000 \mathrm{r} "\end{array}$ & $\begin{array}{l}30 \\
30 \\
32\end{array}$ & $\begin{array}{l}49.5 \\
42.9 \\
36.6\end{array}$ & $\begin{array}{l}42.1 \\
39.0 \\
35.4\end{array}$ & $\begin{array}{l}36.4 \\
35.0 \\
31.4\end{array}$ & $\begin{array}{l}26.6 \\
26.3 \\
19.8\end{array}$ & $\begin{array}{l}39.1 \pm 1.68 \\
36.1 \pm 1.33 \\
30.8 \pm 1.31\end{array}$ \\
\hline $\begin{array}{l}0.94 \times 10^{13} \mathrm{~N}_{\mathrm{th}} / \mathrm{cm}^{2} \\
1.84 \times 10^{13}, ", \\
3.60 \times 10^{13}\end{array}$ & $\begin{array}{l}32 \\
31 \\
29\end{array}$ & $\begin{array}{l}45.6 \\
46.4 \\
43.0\end{array}$ & $\begin{array}{l}41.9 \\
41.9 \\
35.6\end{array}$ & $\begin{array}{l}36.0 \\
36.4 \\
35.0\end{array}$ & $\begin{array}{l}26.8 \\
29.4 \\
17.7\end{array}$ & $\begin{array}{l}37.6 \pm 1.44 \\
38.8 \pm 1.23 \\
33.2 \pm 1.95\end{array}$ \\
\hline
\end{tabular}

fects upon root length would doubtless have been more pronounced if a considerably longer germination time had been employed.

Mean dimensions of cells in the two regions described in the preceding section are presented in table 2, and counts of dividing cells are shown in table 3. Consideration of the group means disclosed no association between cell size or mitotic activity and root length within treatments; consequently, only treatment means are shown in the tables. No relationship of cell width to treatment is apparent from the data. With respect to cell length in both region I and region II, however, small increases were observed with increasing dose of either X-rays or thermal neutrons. In contrast to the apparently minor effect upon cell size, a rather drastic depressive effect of the treatments upon mitotic activity is indicated by the data.

TABLE 2

DIMENSIONS OF CELLS IN TIPS OF PRIMARY ROOTS FROM CONTROL AND IRRADIATED SEEDS OF MAIZE. REGIONS I AND II ARE DESCRIBED IN TEXT

\begin{tabular}{|c|c|c|c|c|c|}
\hline \multirow{3}{*}{ Treatment } & \multirow{3}{*}{$\begin{array}{l}\text { No. of } \\
\text { determi- } \\
\text { nations }\end{array}$} & \multicolumn{4}{|c|}{ Cell dimensions $(\mu)$} \\
\hline & & \multicolumn{2}{|c|}{ Region I } & \multicolumn{2}{|c|}{ Region II } \\
\hline & & Width & Length & Width & Length \\
\hline & & mean \pm S.E. & mean \pm S.E. & mean $\pm S . E$. & mean \pm S.E. \\
\hline Control & 120 & $16.3 \pm 0.44$ & $10.5 \pm 0.25$ & $18.4 \pm 0.39$ & $10.2 \pm 0.47$ \\
\hline $\begin{array}{l}10,000 \text { r X-ray } \\
20,000 \text { r "," } \\
40,000 \text { r " }\end{array}$ & $\begin{array}{l}100 \\
120 \\
120\end{array}$ & $\begin{array}{l}16.9 \pm 0.39 \\
17.6 \pm 0.42 \\
15.8 \pm 0.46\end{array}$ & $\begin{array}{l}11.1 \pm 0.34 \\
10.9 \pm 0.27 \\
13.2 \pm 0.35\end{array}$ & $\begin{array}{l}16.6 \pm 0.36 \\
18.6 \pm 0.32 \\
18.3 \pm 0.26\end{array}$ & $\begin{array}{l}9.3 \pm 0.46 \\
10.6 \pm 0.50 \\
12.0 \pm 0.64\end{array}$ \\
\hline $\begin{array}{l}0.94 \times 10^{13} \mathrm{~N}_{\mathrm{th}} / \mathrm{cm}^{2} \\
1.84 \times 10^{13} \quad, " \\
3.60 \times 10^{13} \quad, "\end{array}$ & $\begin{array}{r}115 \\
120 \\
95\end{array}$ & $\begin{array}{l}16.2 \pm 0.44 \\
16.3 \pm 0.46 \\
15.5 \pm 0.57\end{array}$ & $\begin{array}{l}11.1 \pm 0.27 \\
12.3 \pm 0.32 \\
13.0 \pm 0.38\end{array}$ & $\begin{array}{l}18.1 \pm 0.37 \\
18.5 \pm 0.30 \\
18.1 \pm 0.33\end{array}$ & $\begin{array}{l}10.1 \pm 0.49 \\
10.4 \pm 0.59 \\
10.8 \pm 0.62\end{array}$ \\
\hline
\end{tabular}


TABLE 3

NUMBER OF DIVIDING CELLS IN ROOT TIPS FROM CONTROL AND IRRADIATED SEEDS OF MAIZE

\begin{tabular}{lcc}
\hline Treatment & $\begin{array}{c}\text { Number of } \\
\text { determinations }\end{array}$ & $\begin{array}{c}\text { Number of } \\
\text { dividing cells } \\
\text { per section }\end{array}$ \\
\hline Control & 240 & mean \pm S.E. \\
$10,000 \mathrm{rX}$-ray & 200 & $14.9 \pm 0.42$ \\
$20,000 \mathrm{r} "$, & 240 & $9.7 \pm 0.30$ \\
$40,000 \mathrm{r} "$ & 240 & $6.7 \pm 0.22$ \\
$0.94 \times 10^{13} \mathrm{~N} \mathrm{Nh}^{\prime} / \mathrm{cm}^{2}$ & 230 & $5.8 \pm 0.29$ \\
$1.84 \times 10^{\mathbf{1}^{3}}, "$ & 240 & $9.0 \pm 0.35$ \\
$3.60 \times 10^{13}$ & 190 & $6.0 \pm 0.24$ \\
\hline
\end{tabular}

It would be expected that any treatment influencing cell number or cell size in the root would have an effect upon root length. Thus, irradiationinduced decreases in mitotic activity, and hence in cell number, would tend to reduce root length while irradiation-induced increases in cell length would tend to increase root length. With respect to root length in the present study, the effects of irradiation upon cell number and cell length partially offset each other. Schwartz and Bay (1956) noted that in root tips growing from maize seeds which had been subjected to extremely high doses (up to 500,000 r) of gamma rays, mitotic activity was completely arrested and the cells were much elongated.

In other work on the same lots of irradiated and control seed as were used in the experiments on cell size and mitotic activity, assays were made of the desoxyribonucleic acid (DNA) and ribonucleic acid (RNA) in the terminal 3-mm. portion of the root tip. A modification of the procedure of Ogur and Rosen (1950) was used for these assays. A tendency was observed toward decreased amounts of RNA per root tip with increasing dose of $\mathrm{X}$-rays or thermal neutrons, but no consistent relationship was found between DNA content and dose. In view of the definite irradiation-induced depression of mitotic activity, the failure to detect significant reductions in DNA content in the irradiated material was rather surprising. Cell dimensions indicated, however, that differences between treatments with respect to number of cells in the terminal 3-mm. portion of the root were probably not great; thus, large differences in DNA content probably should not have been expected. If differences did indeed exist, they were not detected by the analytical procedures which were followed.

\section{SUMMARY}

Cell size, mitotic activity, and nucleic acid content were determined using tips of roots produced by the germination of control, X-irradiated, and thermal neutron-irradiated maize seeds. The dosage levels used had no 
appreciable effect upon cell width, but small increases in cell length were associated with increasing dose of irradiation. The treatments effected drastic reductions in mitotic activity. A tendency was observed toward decreased amounts of ribonucleic acid per root tip with increasing dose of irradiation, but no consistent relationship was found between desoxyribonucleic acid content and dose.

\section{LITERATURE CITED}

Caldecott, R. S., 1955, The effects of X-rays, 2-mev electrons, thermal neutrons, and fast neutrons on dormant seeds of barley. Ann. N. Y. Acad. Sci. 59: 514-535.

Caldecott, R. S., B. H. Beard and C. O. Gardner, 1954, Cytogenet ic effects of X-ray and thermal neutron irradiation on seeds of barley. Genetics 39: 240-259.

Caldecott, R. S., E. F. Frolik and R. Morris, 1952, A comparis on of the effects of $\mathrm{X}$-rays and thermal neutrons on dormant seeds of barley. Proc. Nat. Acad. of Sci. 38: 804-809.

Haskins, F. A., and H.W. Chapman, 1956, Effects of irradiation, maleic hydrazide, temperature, and age on enzyme activity in seedlings of corn (Zea mays L.). Physiologia Plantarum 9: 356-362.

Lea, D. E., 1955, Actions of radiations on living cells. Second Edition. 416 pages. Cambridge University Press, Cambridge.

Ogur, M., and G. Rosen, 1950, The nucleic acids of plant tissues. I. The extraction and estimation of desoxypentose nucleic acid and pentose nucleic acid. Arch. Bioch. 25: 262-276.

Randolph, L. F., 1935, A new fixing fluid and a revised schedule for the paraffin method in plant cytology. Stain Technology 10: 95-96.

Schmidt, J. W., and E. F. Frolik, 1951, The effects of thermal-neutron irradiation of maize and barley kernels. Nebraska Agr. Exp. Sta. Res. Bull. 167. 29 pages.

Schwartz, D., 1954, An interesting phenomenon associated with irradiation of dry maize seeds. Science 119: 45-46.

Schwartz, D., and C. E. Bay, 1956, Further studies on the reversal in the seedling height dose curve at very high levels of ionizing radiations. Amer. Nat. 90: 323-327.

Spencer, J. L., and E. Cabanillas, 1956, The effects of X-rays and thermal neutrons on the development of trailing indigo (Indigofera endecapbylla) plants. Amer. J. Bot. 43: 289-296.

Yagyu, P., and R. Morris, 1957, Cytogenetic effects of X-rays and thermal neutrons on dormant tomato seeds. Genetics 42: 222-238. 